\title{
Utilization of ileal digestible amino acids by growing pigs: tryptophan
}

\author{
BY E. S. BATTERHAM, L. M. ANDERSEN AND D. R. BAIGENT* \\ NSW Agriculture, Wollongbar Agricultural Institute, Wollongbar, New South Wales 2477 , \\ Australia
}

(Received 10 November 1992 - Revised 17 March 1993 - Accepted 16 April 1993)

\begin{abstract}
The ileal digestibility of tryptophan for growing pigs was determined for cottonseed, meat-and-bone and soya-bean meals. Tryptophan in the food and digesta was measured by two analytical procedures $(\mathrm{NaOH}$ hydrolysis and colorimetric estimation (method 1) and LiOH hydrolysis and HPLC determination (method 2)). The results were respectively: cottonseed meal $0.46,0.81$; meat-and-bone meal $0.55,0.65$; soya-bean meal $0.74,0.90$. In the first experiment the values for method 1 were shown to be inapplicable to pigs. In a second experiment three tryptophan-deficient diets (0.05 $\mathrm{g}$ ileal digestible tryptophan/MJ digestible energy (DE)) were formulated using values from method 2 for cottonseed meal, meat-and-bone meal plus L-tryptophan and soya-bean meal respectively as the only sources of tryptophan in the diets. This experiment was terminated after $28 \mathrm{~d}$ as overall growth performance of the pigs was very low. A third experiment was conducted in a similar manner to Expt 2 except that the diets were formulated to $0.065 \mathrm{~g}$ ileal digestible tryptophan/MJ DE and growth responses and tryptophan retention were assessed over the $20-45 \mathrm{~kg}$ growth phase. Growth rates $(\mathrm{g} / \mathrm{d})$ of the pigs given the three diets were significantly different $(P<0.01)$ : cottonseed meal 393, meat-and-bone meal plus L-tryptophan 531, soya-bean meal 437 (SED 39.0). Tryptophan retention (as a proportion of ileal digestible tryptophan intake) was significantly different $(P<0.05)$ : cottonseed meal 0.51 , meat-and-bone meal plus L-tryptophan 0.49, soya-bean meal $0 \cdot 41$. These results indicate (1) that the colorimetric technique for assessing tryptophan was inapplicable and (2) that ileal digestible values for tryptophan were not suitable for formulating diets containing heat-processed proteins, possibly due to absorption of some of the tryptophan in a form that was non-utilizable, and/or to underestimation of total tryptophan in the protein concentrates.
\end{abstract}

Tryptophan: Ileal digestibility: Pigs

The ileal digestibility of amino acids is commonly used to estimate the availability of amino acids for the growing pig. However, values for the ileal digestibility of lysine, threonine and methionine have been shown to be unsuitable for formulating diets in certain heatprocessed protein concentrates, as a considerable portion of these amino acids appear to be absorbed in a form(s) that is (are) inefficiently utilized (Batterham et al. 1990a, 1993; Beech et al. 1991). It appears that ileal digestibility values for these amino acids overestimate availability in heat-processed meals.

As a number of amino acids are affected, it is possible that chemical reactions occur between amino acids within a protein molecule rather than specific Maillard reactions between lysine and carbonyl groups of reducing sugars. As such, other amino acids in addition to threonine and methionine may also be affected.

The present paper reports experiments that examined the utilization of ileal digestible tryptophan by growing pigs. Tryptophan is a difficult amino acid to determine as it is

* Present address: Department of Food and Agriculture, Institute for Sustainable Agriculture, Tatura, Victoria 3616, Australia. 
destroyed by the acid-hydrolysis used to hydrolyse amino acids from protein concentrates. It is normally determined by colorimetric estimation or HPLC following alkalinehydrolysis. There is considerable uncertainty regarding methodology and consequently there is uncertainty about the tryptophan contents in feeds and the estimates of the growing pig's requirement for tryptophan. The aims of the current work were to determine (1) the ileal digestibility of tryptophan when this amino acid was measured in food and digesta by two analytical procedures, (2) whether values for the ileal digestibility of tryptophan were suitable for formulating diets, and (3) the utilization of ileal digestible tryptophan.

\section{EXPERIMENTAL}

\section{Protein concentrates}

The three protein concentrates used were a 'prepress' solvent-extracted cottonseed meal, a meat-and-bone meal and a 'prepress' solvent-extracted soya-bean meal (Table 1). These three meals represented the range in estimated availability of lysine in protein concentrates (Standing Committee on Agriculture, 1987). Cottonseed meal represents a meal of estimated low lysine availability $(0 \cdot 40)$. It contains no antinutritional factors for pigs, other than free gossypol. This can be inactivated by the addition of $\mathrm{FeSO}_{4}$ to the diet, which binds the free gossypol (Tanksley \& Knabe, 1981). Pigs can tolerate $100 \mathrm{mg}$ free gossypol $/ \mathrm{kg}$ in the diet without effect, or at least $500 \mathrm{mg} / \mathrm{kg}$ with $\mathrm{FeSO}_{4}$ (free gossypol-iron $1: 1, \mathrm{w} / \mathrm{w})$. This is over twice the levels of free gossypol contained in the diets that were used in these studies $(218 \mathrm{mg} / \mathrm{kg})$. Meat-and-bone meal is of medium lysine availability $(0 \cdot 70)$. Provided $\mathrm{Zn}$ and Fe levels are adequate, pigs can tolerate the Ca contributed by these meals. Soya-bean meal represents a meal of high lysine availability $(0.88)$ and adequately processed meal contains no antinutritional factors for pigs.

\section{Ileal digestibility of tryptophan}

The ileal digestibility of amino acids in the three protein concentrates was determined previously with pigs fitted with $T$-shaped cannulas and the results reported by Batterham et al. $(1990 a)$. In that work the ileal digestibility of tryptophan was determined using two different analytical procedures to determine tryptophan in the food and digesta. The first was based on alkaline-hydrolysis with $\mathrm{NaOH}$ (Hugli \& Moore, 1972) and colorimetric estimation of tryptophan. The second was by alkaline-hydrolysis with $\mathrm{LiOH}$ and estimation of tryptophan by HPLC (Degussa AG, 1986). The tryptophan contents in the three meals, together with the ileal digestibilities determined with these techniques, are presented in Table 1.

\section{Expt 1. Formulating diets to $0.05 \mathrm{~g}$ ileal digestible tryptophan $/ M J D E$ using values determined colorimetrically following sodium hydroxide hydrolysis}

Diets. Three diets were formulated to contain $0.05 \mathrm{~g}$ ileal digestible tryptophan/MJ digestible energy (DE; diets nos. 1, 2 and 3; Table 2). This level of tryptophan was chosen after considering the relationship between tryptophan and lysine. In previous studies with lysine a level of $0.36 \mathrm{~g}$ ileal digestible lysine/MJ DE was used as it represents an area on the response curve where the growth rate of the pig responds in a linear manner to lysine concentration, while being near the area where lysine retention plateaus (Batterham et al. $1990 \mathrm{~b}$ ). A similar relationship was assumed for tryptophan and the level of $0.05 \mathrm{~g}$ ileal digestible tryptophan/MJ DE was based on the tryptophan being approximately 0.14 of lysine needs (Agricultural Research Council, 1981). At this level, however, it was not 
Table 1. Composition ( $\mathrm{g} / \mathrm{kg}$, air-dry basis) of the cottonseed meal, meat-and-bone meal and soya-bean meal

\begin{tabular}{|c|c|c|c|}
\hline & Cottonseed meal & Meat-and-bone meal & Soya-bean meal \\
\hline Crude protein $(\mathrm{N} \times 6.25)$ & 408 & 525 & 463 \\
\hline Dry matter & 885 & 953 & 883 \\
\hline Light petroleum (b.p. $40-60^{\circ}$ ) extract & 17 & 95 & 14 \\
\hline \multicolumn{4}{|l|}{ Fibre } \\
\hline Crude & 102 & - & 43 \\
\hline Neutral-detergent & 296 & - & 111 \\
\hline Ash & 63 & 323 & 66 \\
\hline \multicolumn{4}{|l|}{ Amino acids } \\
\hline Aspartic acid & $39 \cdot 7$ & 36.0 & 53.2 \\
\hline Threonine & 14.9 & $16 \cdot 8$ & $19 \cdot 2$ \\
\hline Serine & $20 \cdot 6$ & 22.4 & $25 \cdot 3$ \\
\hline Glutamic acid & $86 \cdot 1$ & $64 \cdot 2$ & $85 \cdot 9$ \\
\hline Glycine & 17.7 & 77.4 & 20.1 \\
\hline Alanine & 16.7 & 42.7 & 20.2 \\
\hline Cystine & 8.5 & $6 \cdot 3$ & $9 \cdot 1$ \\
\hline Valine & $15 \cdot 5$ & $18 \cdot 2$ & 16.8 \\
\hline Methionine & $6 \cdot 4$ & $7 \cdot 7$ & $7 \cdot 0$ \\
\hline Isoleucine & $11 \cdot 7$ & $12 \cdot 1$ & 17.5 \\
\hline Leucine & $25 \cdot 1$ & 28.9 & $35 \cdot 0$ \\
\hline Tyrosine & 11.8 & $11 \cdot 0$ & 16.0 \\
\hline Phenylalanine & 21.6 & 15.8 & $22 \cdot 9$ \\
\hline Histidine & 13.5 & $13 \cdot 2$ & 13.9 \\
\hline Lysine & 19.7 & 25.6 & 26.9 \\
\hline Arginine & 47.9 & 39.5 & $35 \cdot 4$ \\
\hline \multicolumn{4}{|l|}{ Tryptophan* } \\
\hline Method 1 & 4.6 & $2 \cdot 2$ & $5 \cdot 3$ \\
\hline Method 2 & $5 \cdot 3$ & 2.7 & 6.8 \\
\hline \multicolumn{4}{|l|}{$\begin{array}{l}\text { Apparent ileal digestibility of } \\
\text { tryptophan (proportion of total) } \dagger\end{array}$} \\
\hline Method 1 & 0.46 & 0.55 & 0.74 \\
\hline Method 2 & 0.81 & 0.65 & 0.90 \\
\hline
\end{tabular}

* Method 1, NaOH hydrolysis, colorimetric estimation; method 2, LiOH hydrolysis, HPLC determination; for details of methods, see p. 351. The standard deviations for method 1 were: $0 \cdot 040,0 \cdot 017$ and $0 \cdot 031$ for cottonseed, meat-and-bone and soya-bean meals respectively.

$\uparrow$ Standard errors of difference: method 1, 0.070; method 2, 0.025 .

possible to supply all the tryptophan from meat-and-bone meal (diet no. 2) without excessive dietary Ca levels. Accordingly, the level of meat-and-bone meal was restricted to $275 \mathrm{~g} / \mathrm{kg}$, and free L-tryptophan was added to bring the dietary level to the desired concentration. The meat-and-bone meal supplied approximately half the ileal digestible tryptophan in diet no. 2. To ensure that tryptophan was the limiting amino acid in the diet, supplements of other essential amino acids were added to provide a minimum of $0 \cdot 3$ surplus, relative to tryptophan, according to the estimate of the Agricultural Research Council (1981), Fuller \& Wang (1987) and as estimated by computer simulation studies using the 'Auspig' model (Black et al. 1986) for the Wollongbar genotype.

Diets nos. 4, 5 and 6 were supplemented with tryptophan to verify that tryptophan was limiting in diets nos. 1-3. The DE content of the three protein concentrates was determined previously (Batterham et al. 1990a) and the digestible energy content of the other ingredients was estimated from previous determinations at this Institute.

Animals and procedures. The six diets were arranged in a randomized block design. Ten 
Table 2. Expt 1. Composition $(\mathrm{g} / \mathrm{kg}$, air dry-basis) of the diets formulated to 0.05 or $0.064 \mathrm{~g}$ ileal digestible tryptophan/MJ digestible energy (DE) using values for tryptophan determined colorimetrically following sodium hydroxide hydrolysis

\begin{tabular}{|c|c|c|c|c|c|c|}
\hline Diet no.... & 1 & 2 & 3 & 4 & 5 & 6 \\
\hline \multicolumn{7}{|l|}{ Components } \\
\hline Cottonseed meal & 340 & - & - & 340 & - & - \\
\hline Meat-and-bone meal & - & 275 & - & - & 275 & - \\
\hline Soya-bean meal & - & - & 201 & - & - & 201 \\
\hline L-Tryptophan & - & 0.43 & - & 0.21 & 0.65 & 0.23 \\
\hline Amino acids* & $5 \cdot 48$ & $10 \cdot 46$ & 11.98 & $5 \cdot 48$ & $10 \cdot 46$ & 11.98 \\
\hline Monosodium glutamate & - & - & 13 & - & - & 13 \\
\hline Mineral and vitamin premix $\dagger$ & 5 & $10 \cdot 10$ & 5 & 5 & $10 \cdot 10$ & 5 \\
\hline Dicalcium phosphate & 30 & - & 30 & 30 & - & 30 \\
\hline $\mathrm{FeSO}_{4} .7 \mathrm{H}_{2} \mathrm{O}$ & $1 \cdot 10$ & $0 \cdot 25$ & - & $1 \cdot 10$ & 0.25 & - \\
\hline Soya-bean oil & 15 & 15 & 15 & 15 & 15 & 15 \\
\hline Sucrose & 603.42 & $688 \cdot 76$ & $724 \cdot 02$ & $603 \cdot 21$ & $688 \cdot 54$ & $723 \cdot 79$ \\
\hline \multicolumn{7}{|l|}{ Composition } \\
\hline DE (estimated) $(\mathrm{MJ} / \mathrm{kg})$ & $14 \cdot 3$ & $15 \cdot 3$ & $15 \cdot 6$ & $14 \cdot 3$ & $15 \cdot 3$ & $15 \cdot 6$ \\
\hline \multicolumn{7}{|l|}{ Ileal digestible tryptophan } \\
\hline $\mathrm{g} / \mathrm{kg}$ & 0.714 & 0.760 & 0.784 & 0.924 & 0.980 & 1.008 \\
\hline $\mathrm{g} / \mathrm{MJ} \mathrm{DE}$ & 0.05 & $0 \cdot 05$ & 0.05 & 0.064 & 0.064 & 0.064 \\
\hline
\end{tabular}

* Contributed the following $(\mathrm{g} / \mathrm{kg})$ to the cottonseed, meat-and-bone meal and soya-bean meal diets respectively: DL-methionine $0.56,1.0,1.3 ;$ L-threonine $0.57,1.0,1.37 ;$ L-valine $0.59,1.38,2.54 ;$ L-isoleucine 0.24 , $1 \cdot 13,0.71$; L-leucine $0.2,1 \cdot 08,1 \cdot 2$; L-phenylalanine $0,1 \cdot 24,0.3$; L-histidine $0.37,1.63,1.42$; L-lysine hydrochloride $2 \cdot 95,2 \cdot 0,3 \cdot 14$

$\dagger$ Contributed the following (mg/kg diet): $\mathrm{Fe} 60, \mathrm{Zn} \mathrm{100,} \mathrm{Mn} \mathrm{30,} \mathrm{Cu} \mathrm{5,} \mathrm{I} \mathrm{2,} \mathrm{NaCl} 2 \cdot 8 \mathrm{~g}$, Se 0.15, retinol equivalent $960 \mu \mathrm{g}$, cholecalciferol $12 \mu \mathrm{g}$, $\alpha$-tocopherol 20, thiamine 1.5, riboflavin 3, nicotinic acid 14, pantothenic acid 10 , pyridoxine $2 \cdot 5$, cyanocobalamin $15 \mu \mathrm{g}$, pteroylmonoglutamic acid 2 , choline 500 , ascorbic acid 10 , biotin $0 \cdot 1$ and menadione (as menadione sodium bisulphite) $1 \cdot 2$. Additional supplements of $\mathrm{ZnO}(100 \mathrm{mg} / \mathrm{kg})$ and $\mathrm{K}_{2} \mathrm{SO}_{4}(5 \mathrm{~g} / \mathrm{kg})$ were added to diets 2 and 5 .

Large White pigs (six male, four female) were allotted per diet (nine for diet 2, five males, four females). The pigs were blocked on 7-week weight, sex and position in the experimental facilities. The pigs were penned individually and water was supplied by nipple drinkers.

Dietary treatments were introduced when the pigs reached $20 \mathrm{~kg}$ live weight. The diets were offered at a feeding scale of three times maintenance ( $0.5 \mathrm{MJ} \mathrm{DE} / \mathrm{kg}$ live weight $\mathrm{t}^{0.75}$ ). The pigs were fed every $3 \mathrm{~h}$ with an automatic feeder to ensure the efficient utilization of the added free amino acids (Batterham \& Murison, 1981). The feed was offered dry and daily feeding rates were adjusted after the weekly weighings of the pigs.

After reaching a minimum weight of $45 \mathrm{~kg}$ the pigs were slaughtered by electric stunning and hot carcass weight and backfat depth at the $\mathrm{P}_{2}$ position determined with an introscope. Pig response was assessed in terms of daily live-weight gain, food conversion ratio (FCR), killing-out proportion, gain/d and FCR on a carcass basis, and backfat thickness $\left(\mathrm{P}_{2}\right)$. $\mathrm{A}$ factor of 0.730 was used to convert initial live weight at $20 \mathrm{~kg}$ to estimated carcass weight. This factor was determined previously with eight pigs slaughtered at $20 \mathrm{~kg}$ live weight.

The results were analysed by analysis of variance and treatment means separated by least significant difference (LSD). 
Table 3. Expt 2. Composition ( $\mathrm{g} / \mathrm{kg}$, air dry-basis) of the diets formulated to 0.05 or $0.064 \mathrm{~g}$ ileal digestible tryptophan/MJ digestible energy (DE) using values for tryptophan determined by HPLC following lithium hydroxide hydrolysis

\begin{tabular}{|c|c|c|c|c|c|c|}
\hline Diet no.... & 1 & 2 & 3 & 4 & 5 & 6 \\
\hline \multicolumn{7}{|l|}{ Components } \\
\hline Cottonseed meal & 175 & - & - & 175 & - & - \\
\hline Meat-and-bone meal & - & 275 & - & - & 275 & - \\
\hline Soya-bean meal & _- & - & 129 & - & - & 129 \\
\hline L-Tryptophan & - & 0.27 & - & 0.22 & 0.48 & 0.23 \\
\hline Amino acids* & $23 \cdot 8$ & 11.70 & 24.6 & $23-8$ & $11 \cdot 70$ & $24 \cdot 6$ \\
\hline Monosodium glutamate & 13 & - & 24 & 13 & - & 24 \\
\hline Mineral and vitamin premix $\dagger$ & 5 & $10 \cdot 10$ & 5 & 5 & $10 \cdot 10$ & 5 \\
\hline Dicalcium phosphate & 30 & - & 30 & 30 & - & 30 \\
\hline $\mathrm{FeSO}_{4} .7 \mathrm{H}_{2} \mathrm{O}$ & 0.6 & 0.25 & - & 0.6 & 0.25 & - \\
\hline Soya-bean oil & 15 & 15 & 15 & 15 & 15 & 15 \\
\hline Sucrose & 737.6 & 687.68 & $772 \cdot 4$ & $737 \cdot 38$ & $687 \cdot 47$ & $772 \cdot 17$ \\
\hline \multicolumn{7}{|l|}{ Composition } \\
\hline $\mathrm{DE}$ (estimated) $(\mathrm{MJ} / \mathrm{kg})$ & $15 \cdot 1$ & $15 \cdot 3$ & $15 \cdot 7$ & $15 \cdot 1$ & $15 \cdot 3$ & $15 \cdot 7$ \\
\hline \multicolumn{7}{|l|}{ Ileal digestible tryptophan } \\
\hline $\mathrm{g} / \mathrm{kg}$ & 0.751 & 0.753 & 0.789 & 0.971 & 0.963 & 1.019 \\
\hline $\mathrm{g} / \mathrm{MJ} \mathrm{DE}$ & 0.05 & 0.05 & 0.05 & 0.064 & 0.064 & 0.064 \\
\hline
\end{tabular}

* Contributed the following $(\mathrm{g} / \mathrm{kg})$ to the cottonseed, meat-and-bone meal and soya-bean meal diets respectively: DL-methionine $2 \cdot 0,1 \cdot 55,2.6$; L-threonine $2.45,1.0,2.45$; L-valine $3.05,1.4,3.65$; L-isoleucine 2.05 , $1 \cdot 15,1 \cdot 85$; L-leucine $3 \cdot 85,1 \cdot 1,3 \cdot 5$; L-tyrosine $1 \cdot 85,1 \cdot 25,1 \cdot 65$; L-phenylalanine $0 \cdot 8,0 \cdot 60,1 \cdot 55$; L-histidine 1.65, 1.65, $2 \cdot 00$; L-lysine hydrochloride $6 \cdot 1,2 \cdot 0,5 \cdot 35$.

$\dagger$ For details of composition, see Table 2.

Expt 2. Formulating diets to $0.05 \mathrm{~g}$ ileal digestible tryptophan $/ M J D E$ using values determined by HPLC following lithium hydroxide hydrolysis

Diets, animals and procedures. The diets were formulated in a similar manner to Expt 1 (Table 3). Allocation of animals and experimental procedures were similar to Expt 1 except there were five males and five females per treatment.

It became evident that although there was a strong response to tryptophan supplementation of the diets (diets nos. 4-6), overall growth performance of the pigs on all treatments was very poor. Rather than continue the experiment over the $20-45 \mathrm{~kg}$ growth phase it was decided to restrict it to a $28 \mathrm{~d}$ time-period.

The pigs were then slaughtered by electric stunning. The blood was collected and the viscera washed to remove undigested material. The blood and washed viscera were then combined and frozen. The carcasses (with hair) were washed clean with water, split longitudinally down the middle of the vertebrae and the left-hand side stored at $-15^{\circ}$, then ground, mixed, sampled and freeze-dried before chemical analyses. The mixed blood and washed viscera were processed in a similar manner.

In order to determine nutrient retentions, five male and five female pigs were slaughtered at the commencement of the experiment ( $20 \mathrm{~kg}$ live weight) and the chemical composition of the blood plus washed viscera and whole carcasses determined in a similar manner as for the pigs slaughtered after $28 \mathrm{~d}$ on experimental diets.

Pig response was assessed in terms of live-weight gain; daily gain; food intake; FCR; empty-body weight:final live weight; gain/d and FCR on an empty-body-weight basis; protein, fat and energy content in the empty body; protein, fat and energy deposition/d; protein and energy deposition:DE intake; protein retention:protein intake; tryptophan 
Table 4. Expt 3. Composition $(\mathrm{g} / \mathrm{kg}$, air dry-basis) of the diets formulated to 0.065 or $0.084 \mathrm{~g}$ ileal digestible tryptophan/MJ digestible energy (DE) using values for tryptophan determined by HPLC following lithium hydroxide hydrolysis

\begin{tabular}{|c|c|c|c|c|c|c|}
\hline Diet no.... & 1 & 2 & 3 & 4 & 5 & 6 \\
\hline \multicolumn{7}{|l|}{ Components } \\
\hline Cottonseed meal & 225 & - & $\ldots$ & 225 & - & - \\
\hline Meat-and-bone meal & - & 275 & - & - & 275 & - \\
\hline Soya-bean meal & - & - & 167 & - & - & 167 \\
\hline L-Tryptophan & - & 0.44 & - & 0.29 & 0.71 & $0 \cdot 30$ \\
\hline Amino acids* & $30 \cdot 26$ & $21 \cdot 35$ & $31 \cdot 69$ & $30 \cdot 26$ & $21 \cdot 35$ & $31 \cdot 69$ \\
\hline Monosodium glutamate & 11 & - & 28 & 11 & - & 28 \\
\hline Mineral and vitamin premix $\dagger$ & 5 & $10 \cdot 1$ & 5 & 5 & $10 \cdot 1$ & 5 \\
\hline Dicalcium phosphate & 30 & - & 30 & 30 & - & 30 \\
\hline $\mathrm{FeSO}_{4} \cdot 7 \mathrm{H}_{2} \mathrm{O}$ & 0.72 & 0.25 & & 0.72 & 0.25 & - \\
\hline Soya-bean oil & 15 & 15 & 15 & 15 & 15 & 15 \\
\hline Solka floc & - & 50 & - & - & 50 & - \\
\hline Sucrose & 683.02 & $627 \cdot 86$ & $723 \cdot 31$ & $682 \cdot 73$ & 627.59 & 723.01 \\
\hline \multicolumn{7}{|l|}{ Composition } \\
\hline DE (estimated) $(\mathrm{MJ} / \mathrm{kg})$ & 14.8 & $14 \cdot 4$ & $15 \cdot 7$ & $14 \cdot 8$ & $14 \cdot 4$ & $15 \cdot 7$ \\
\hline \multicolumn{7}{|l|}{ Ileal digestible tryptophan } \\
\hline $\mathrm{g} / \mathrm{kg}$ & 0.968 & 0.935 & 1.019 & $1 \cdot 258$ & 1.205 & 1.319 \\
\hline $\mathrm{g} / \mathrm{MJ} \mathrm{DE}$ & 0.065 & 0.065 & 0.065 & 0.084 & 0.084 & 0.084 \\
\hline
\end{tabular}

* Contributed the following $(\mathrm{g} / \mathrm{kg})$ to the cottonseed, meat-and-bone meal and soya-bean meal diets respectively: DL-methionine $2 \cdot 26,2 \cdot 08,3 \cdot 05 ; \mathrm{L}$-threonine $3 \cdot 13,1 \cdot 97,3 \cdot 18$; L-valine $3 \cdot 92,2 \cdot 62,4 \cdot 72 ; \mathrm{L}$-isoleucine $2 \cdot 66$, $2 \cdot 01,2 \cdot 44$; L-leucine $4 \cdot 94,2 \cdot 78,4 \cdot 55$; L-tyrosine $2 \cdot 37,2 \cdot 01,2 \cdot 15$; L-phenylalanine $1 \cdot 02,1 \cdot 51,2 \cdot 02$; L-histidine $2 \cdot 1$, $2 \cdot 29,2 \cdot 56 ;$ L-lysine hydrochloride $7 \cdot 86,4 \cdot 08,7 \cdot 02$.

$\uparrow$ For details of composition, see Table 2.

retention:total tryptophan intake; tryptophan retention:apparent ileal digestible tryptophan intake.

The following factors were used in the previously described calculations: $6 \cdot 25$ to convert $\mathrm{N}$ to protein (Agricultural Research Council, 1981);0.947 to convert initial live weight to estimated initial empty-body weight; $7 \cdot 8$ to calculate the energy $(\mathrm{MJ} / \mathrm{kg}) ; 137$ to calculate the protein $(\mathrm{g} / \mathrm{kg})$ in the empty bodies of the pigs at the commencement of the experiment (these factors were determined on the five males and five females slaughtered at $20 \mathrm{~kg}$ live weight). Energy stored as protein was calculated as protein $(\mathrm{kg}) \times 24.2$ (Jordan \& Brown, 1970). Fat content was calculated as (total energy - protein energy)/39.6 (Burlacu et al. 1973). The results were analysed by analysis of variance and treatment means separated by LSD. The tryptophan retention data were transformed (arc sine) before analysis and $95 \%$ confidence limits determined.

Expt 3. Formulating diets to $0.065 \mathrm{~g}$ ileal digestible tryptophan/MJ DE using values determined by HPLC following lithium hydroxide hydrolysis

Diets, animals and procedures. The diets were formulated in a similar manner to Expt 2 (Table 4) except that the level of tryptophan was raised to a value of 0.19 relative to lysine. This ratio was based on the findings of Fuller \& Wang (1987) that the ratio was much higher than that reported by the Agricultural Research Council (1981). Allocation of animals and experimental procedures were similar to Expt 2.

After reaching a minimum weight of $45 \mathrm{~kg}$ the pigs were slaughtered by electric stunning. Collection of blood and washed viscera and carcasses (with hair), processing of samples, 
assessment of responses and analyses of results were as for Expt 2. The factors used in the previously described calculations were as for Expt 2 except for 0.923 to convert initial live weight to estimated initial empty-body weight; $8 \cdot 1$ to calculate the energy $(\mathrm{MJ} / \mathrm{kg}) ; 138$ to calculate the protein $(\mathrm{g} / \mathrm{kg})$ in the empty bodies of the pigs at the commencement of the experiment (these factors were determined on the five males and five females slaughtered at $20 \mathrm{~kg}$ live weight).

\section{Chemical analyses}

The techniques used were as reported by Batterham et al. (1990 b). Tryptophan in the feed and ileal digesta samples was determined by two methods. In the first the sample was hydrolysed with $\mathrm{NaOH}$ (Hugli \& Moore, 1972) and the tryptophan content assessed colorimetrically in a spectrophotometer. With the second method tryptophan was determined by HPLC following alkaline-hydrolysis using LiOH (Degussa AG, 1986). This latter technique was used to determine the tryptophan content in the empty-body samples.

\section{RESULTS}

\section{Ileal digestibility of tryptophan}

The tryptophan content in the meals was lower when determined by method $1(\mathrm{NaOH}$ hydrolysis and colorimetric assessment) relative to results with method 2 (LiOH hydrolysis and determination by HPLC; Table 1). The ileal digestibility of tryptophan was also much lower when determined using values from method 1 relative to method 2 (Table 1). The ileal digestibility of tryptophan was significantly higher in soya-bean meal relative to the other two meals $(P<0.05)$ by both techniques. However, the ileal digestibility of tryptophan tended to be higher in meat-and-bone meal relative to cottonseed meal by method 1 , but significantly lower with method $2(P<0.05)$.

\section{Expt 1. Formulating diets to $0.05 \mathrm{~g}$ ileal digestible tryptophan $/ M J D E$ using values} determined colorimetrically following sodium hydroxide hydrolysis

Two pigs (diet 2, MBM; diet $5 \mathrm{MBM}$ plus tryptophan) died with symptoms of gastric haemorrhaging; their results were treated as missing plots in the statistical analyses. All other pigs remained healthy during the experiment.

There was no growth response to the supplements of free tryptophan (diets nos. 4-6; Table 5) indicating that tryptophan was not the limiting amino acid in diets nos. 1-3. Growth responses were higher and FCR lower in pigs given diets containing soya-bean meal relative to cottonseed meal $(P<0 \cdot 05)$.

\section{Expt 2. Formulating diets to $0.05 \mathrm{~g}$ ileal digestible tryptophan $/ M J D E$ using values} determined by HPLC following lithium hydroxide hydrolysis

Growth rate of the pigs given the meat-and-bone meal plus tryptophan diet $(362 \mathrm{~g} / \mathrm{d})$ and formulated to $0.05 \mathrm{~g}$ ileal digestible tryptophan/MJ DE was significantly higher $(P<0.05)$ than for pigs given the cottonseed $(253 \mathrm{~g} / \mathrm{d})$ and soya-bean meal diets $(296 \mathrm{~g} / \mathrm{d}$; $\operatorname{SED} 28.3 \mathrm{~g} / \mathrm{d}$; Table 6$)$. The addition of tryptophan to the three diets increased growth rates and lowered the FCR $(P<0.001)$.

Crude protein deposition was greater in the pigs given meat-and-bone meal $(52 \mathrm{~g} / \mathrm{d})$ relative to those given cottonseed meal $(37 \mathrm{~g} / \mathrm{d} ;$ SED $4.5 \mathrm{~g} / \mathrm{d} ; P<0.05$; Table 6).

Retention of ileal digestible tryptophan was low for all three treatments and there were significant differences between the retentions for pigs given the three diets $(P<0.001)$ : soya-bean meal $(0 \cdot 49)$, meat-and-bone meal $(0 \cdot 28)$ and cottonseed meal $(0 \cdot 12$; Table 7$)$. Tryptophan retention was higher for the tryptophan-supplemented pigs $(P<0.001)$. 


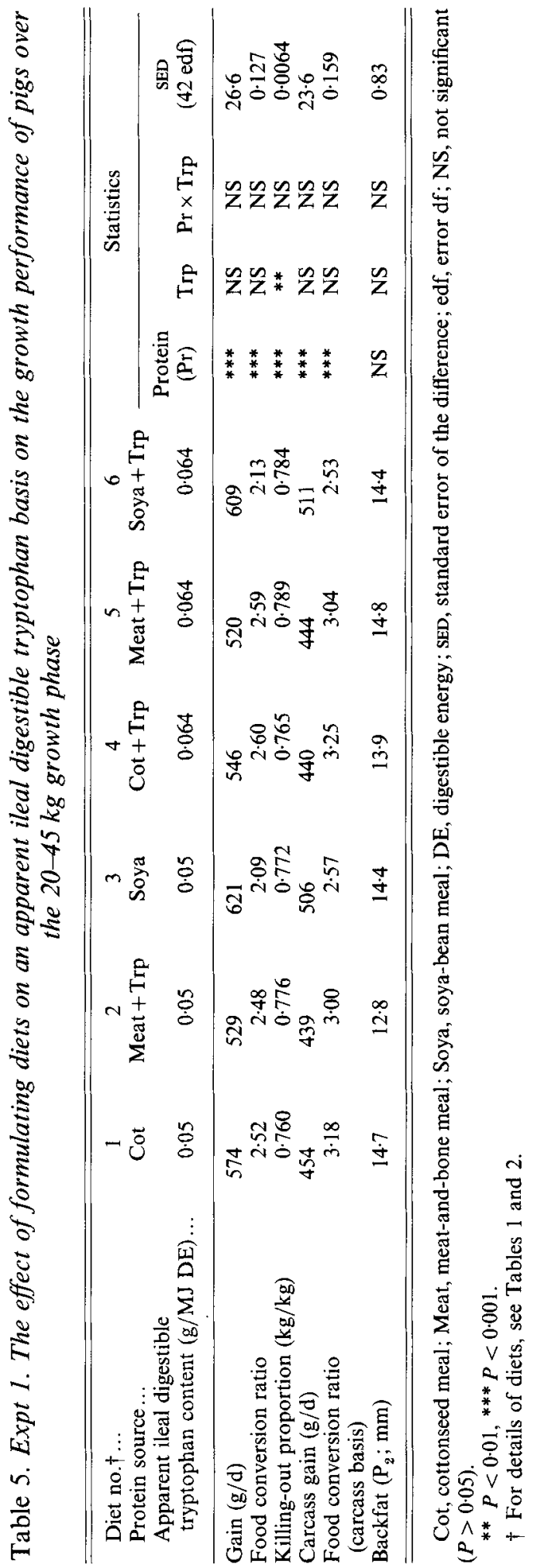




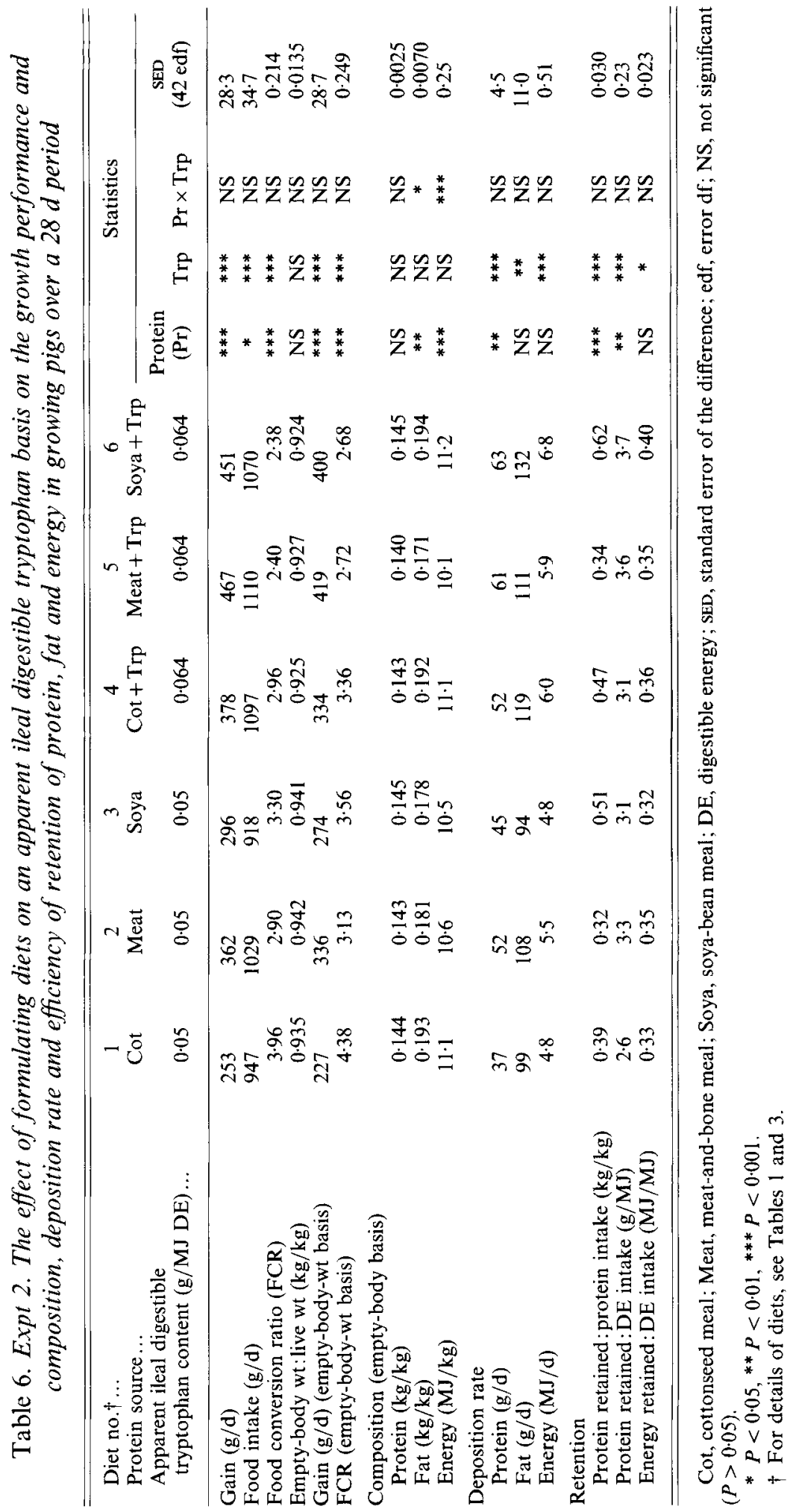




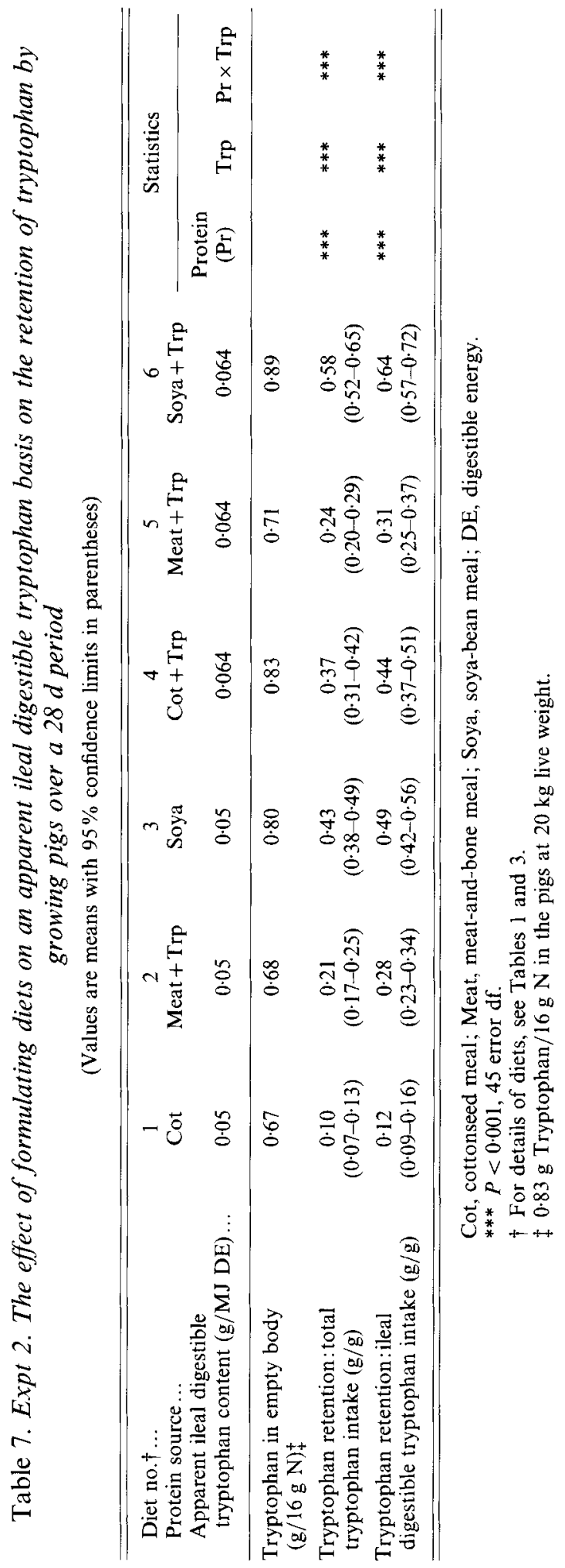




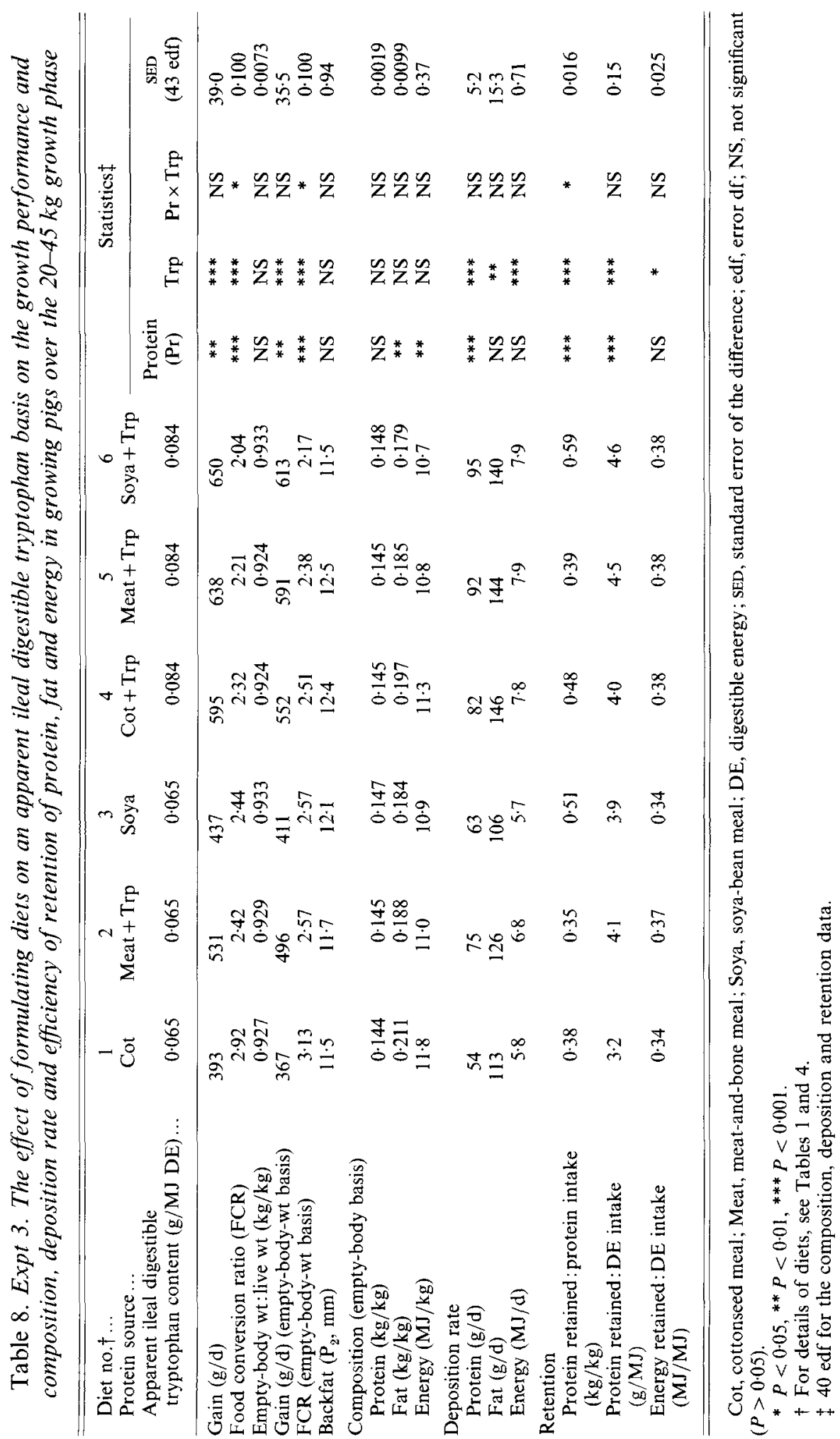




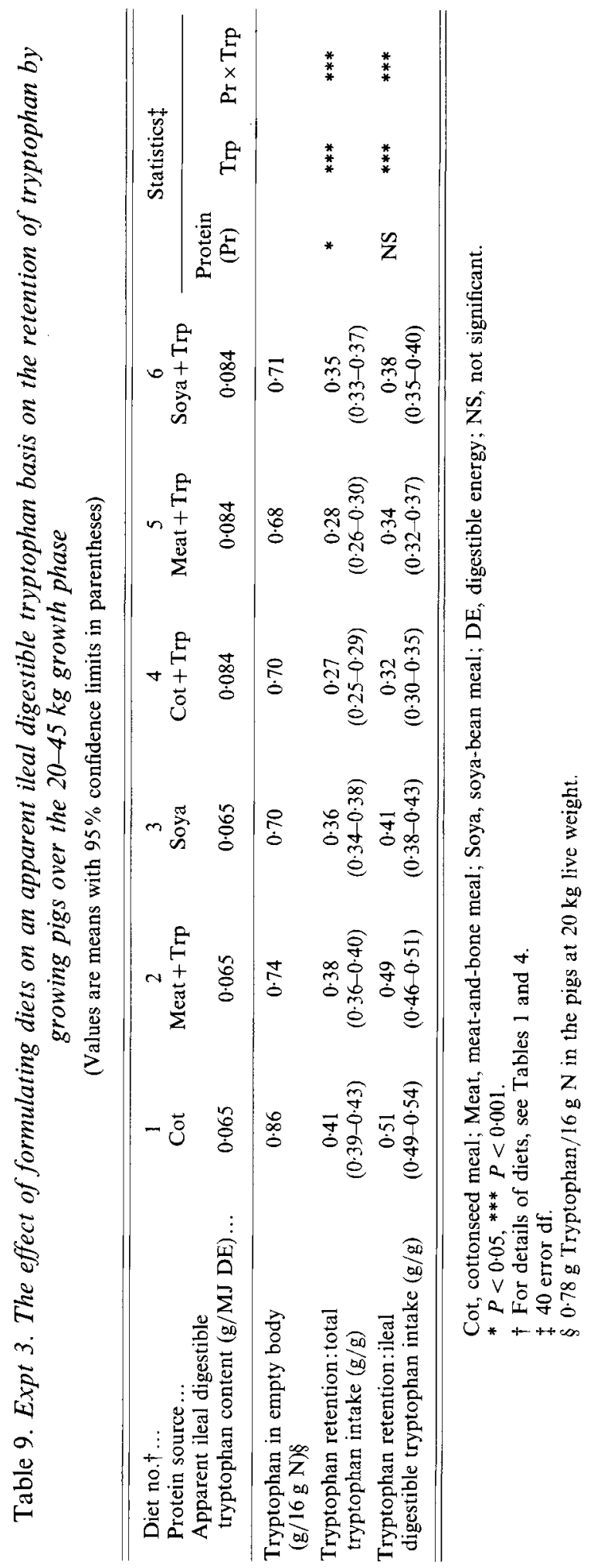




\section{Expt 3. Formulating diets to $0.065 \mathrm{~g}$ ileal digestible tryptophan/MJ DE using values} determined by HPLC following lithium hydroxide hydrolysis

One pig given diet 4 (cottonseed meal plus tryptophan) died with symptoms of mulberry heart disease and one pig given diet 6 (soya-bean meal plus tryptophan) grew slowly and was withdrawn from the experiment. These results were treated as missing plots in the statistical analyses.

Growth rate of the pigs given the meat-and-bone meal plus tryptophan diet $(531 \mathrm{~g} / \mathrm{d})$ and formulated to $0.065 \mathrm{~g}$ ileal digestible tryptophan/MJ DE was significantly higher $(P<0.05)$ than that of pigs given the cottonseed $(393 \mathrm{~g} / \mathrm{d})$ and soya-bean meal diets $(437 \mathrm{~g} / \mathrm{d}$; SED $39.0 \mathrm{~g} / \mathrm{d}$; Table 8$)$. The addition of tryptophan to the three diets increased growth rates and lowered the FCR $(P<0.001)$.

Crude protein deposition was greater in the pigs given the meat-and-bone meal plus tryptophan diet $(75 \mathrm{~g} / \mathrm{d})$ relative to those given soya-bean meal $(63 \mathrm{~g} / \mathrm{d})$ or cottonseed meal (54 g/d; SED $5.2 \mathrm{~g} / \mathrm{d} ; P<0.05$; Table 8$)$.

Retention of ileal digestible tryptophan was low for all three treatments and the retentions for pigs given the meat-and-bone meal plus tryptophan $(0.49)$ and cottonseed meal $(0.51)$ diets were greater $(P<0.05)$ than for those given soya-bean meal $(0.41$; Table 9$)$. Tryptophan retention as a proportion of ileal digestible tryptophan intake was lower for the tryptophan-supplemented pigs $(P<0 \cdot 001)$.

\section{DISCUSSION}

The results of these experiments indicate that $(a)$ there were substantial differences in the biological applicability of the two techniques for assessing tryptophan in feeds and ileal digesta samples, $(b)$ the tryptophan: lysine value is more likely to be $0 \cdot 19$ than $0 \cdot 14$ and $(c)$ there are substantial differences in the response of pigs given diets formulated to similar levels of ileal digestible tryptophan. The results also indicate that the individual variability in response of growing pigs given diets limiting in tryptophan is considerably greater than that associated with the feeding of diets limiting in other amino acids.

\section{Techniques for determining tryptophan}

The lack of response to the tryptophan supplementation of diets nos. 4-6 in Expt 1 (Table 5 ) indicates that tryptophan was not the limiting amino acid in these diets, even though the diets were formulated to contain a surplus of $0 \cdot 3$ of the other essential amino acids. The most likely explanation is that the values for the ileal digestibility of tryptophan were not biologically meaningful to the pig. It appears as if the values underestimated the amount of tryptophan in the meals and overestimated the amount of tryptophan in the ileal samples. For example, the mean values for tryptophan in the samples of ileal digesta, as determined by methods 1 and 2 , were respectively $(\mathrm{g} / \mathrm{kg})$ : cottonseed meal 4.0, 1.6; meatand-bone meal $1.5,1 \cdot 4$; soya-bean meal $2 \cdot 7,1 \cdot 4$. It is possible that the presence of other coloured compounds in the ileal samples interfered with the colorimetric estimation of tryptophan. In contrast, the use of LiOH followed by HPLC assessment (method 2) resulted in a higher extraction of tryptophan in the meals (Table 1) and it was possible to formulate tryptophan-deficient diets in Expts 2 and 3.

\section{Tryptophan:lysine}

The poor performance of the pigs in Expt 2 when the diets were formulated to contain $0.05 \mathrm{~g}$ ileal digestible tryptophan/MJ DE indicates that this level was too low to sustain reasonable growth. In contrast, when the diets were formulated to the higher level of $0.065 \mathrm{~g}$ ileal digestible tryptophan/MJ DE the growth responses were similar to those 
achieved in earlier experiments with lysine (Batterham et al. 1990 a). These results support the findings of Fuller \& Wang (1987) that tryptophan:lysine is 0.19 and not 0.14 as estimated by the Agricultural Research Council (1981). That the ratio is higher than $0 \cdot 14$ is also supported by the recent findings of Lenis et al. (1990).

\section{Utilization of ileal digestible tryptophan}

The significant responses in growth and protein deposition of the pigs to supplements of tryptophan in diets nos. 4-6 confirmed that tryptophan was the limiting amino acid in diets nos. 1-3 in Expts 2 and 3. These results indicate that there are considerable differences in the growth response of pigs given similar levels of ileal digestible tryptophan. In both experiments the highest growth rates and protein depositions were with the pigs given the diet containing meat-and-bone meal plus free tryptophan. The slowest growth rates and protein depositions were recorded with the diets containing cottonseed meal and there was a trend (and in some cases the differences were significant $(P<0.05))$ for the performance of the pigs given the diet containing soya-bean meal to be between the other two.

These results are unusual in that in previous experiments with the same batches of protein concentrates performance had always been greater in pigs given diets containing soya-bean meal relative to meat-and-bone meal, when the diets have been formulated to similar ileal digestible lysine (Batterham et al. 1990a), threonine (Beech et al. 1991) and methionine (Batterham et al. 1993) contents. It seems unlikely that tryptophan would have a relatively lower availability than the previously mentioned amino acids in soya-bean meal and/or a relatively higher availability in meat-and-bone meal. It seems more likely that the addition of free tryptophan to the diet containing meat-and-bone meal, to supply approximately half the ileal digestible tryptophan, was responsible for the improved pig performance. It is difficult to see how this could occur, unless the analyses for total tryptophan in the meat-and-bone meal were underestimating the amount of tryptophan biologically available to the pig. This would be possible if the alkaline hydrolysis conditions did not release all the tryptophan in the meal.

The trend for growth rates and protein depositions to be greater for pigs given the diet containing soya-bean meal relative to those given cottonseed meal in Expts 2 and 3 indicates that some of the ileal digestible tryptophan from the cottonseed meal appears to have been absorbed in a form(s) that is (are) inefficiently utilized. A similar finding was found for lysine (Batterham et al. 1990a), threonine (Beech et al. 1991) and methionine (Batterham et al. 1993). This confirms that during heat processing the changes to the protein molecule appear to be between different amino acids, rather than specific reactions between basic amino acids, such as lysine and carbonyl compounds of reducing sugars (Maillard reactions). However, the smaller differences in performances of the pigs given the tryptophan-deficient cottonseed and soya-bean meal diets compared with the larger differences recorded with lysine-deficient diets (Batterham et al. 1990a) indicates that the differences in tryptophan availability in the meals may be smaller than that for lysine.

The reason that most of the performance results between pigs given diets containing cottonseed and soya-bean meals was non-significant $(P>0.05)$ was that there was considerably greater variation in the growth performances of the individual pigs given the tryptophan-deficient diets. This variation was so great that in some cases individual pigs would be hardly growing whereas other pigs given the same diet would be growing at the rate of the tryptophan-supplemented pigs. This variation is reflected in the substantially higher SED associated with the growth responses: $28-39 \mathrm{~g} / \mathrm{d}$ in expts 2 and 3 respectively compared with $16 \mathrm{~g} / \mathrm{d}$ for lysine-deficient diets (Batterham et al. 1990a). Presumably these differences reflect large individual differences in the requirements for tryptophan, but why this would be different from lysine (or other amino acids) is difficult to explain. 
The overall retentions of ileal digestible tryptophan were low and ranged from 0.12 (cottonseed meal diet) to 0.64 (soya-bean meal diet; Expt 2; Table 7). It seems the very low retention of 0.12 was associated with a high maintenance cost as the pigs grew very poorly on that diet in Expt 2. Even in Expt 3 where higher growth rates were achieved the retentions of ileal digestible tryptophan were only $0.41-0.51$ (Table 9 ). This is considerably less than that achieved for lysine with a diet containing soya-bean meal $(0 \cdot 75$; Batterham et al. $1990 \mathrm{a}$ ). The actual tryptophan levels in the protein of the empty bodies were between 0.67 and $0.89 \mathrm{~g} / 16 \mathrm{~g} \mathrm{~N}$ and did not appear to be affected by the dietary concentration of tryptophan. These levels are similar to tryptophan levels of $0.7-0.86 \mathrm{~g} / 16 \mathrm{~g} \mathrm{~N}$ for $20 \mathrm{~kg}$ live weight pigs reported by Campbell et al. (1988).

\section{Conclusions}

The results indicate that there are considerable difficulties with the methodology of tryptophan analyses, and with the formulation of diets on an ileal digestible tryptophan basis. Values determined by HPLC following $\mathrm{LiOH}$ hydrolysis appear biologically applicable to pigs. In contrast, tryptophan values obtained by colorimetric determination following $\mathrm{NaOH}$ hydrolysis were inapplicable. Differences in growing pig performance resulted when the diets were formulated on an equal ileal digestible tryptophan basis: it was not clear to what extent this was due to underestimation of the total tryptophan in the meals and/or to some of the ileal digestible tryptophan being absorbed in a form that was inefficiently utilized.

The authors are grateful to Messrs R. C. Wilson and A. W. Davis for management of the pigs and skilled technical assistance; Ms E. B. Dettmann and Ms E. J. White for assistance with statistical analyses; Degussa AG, Hanau, for the tryptophan analyses by method 2 and Ajinomoto Co. Inc., Japan for the supply of amino acids. This work was supported by financial grants from the Pig Research and Development Corporation.

\section{REFERENCES}

Agricultural Research Council (1981). The Nutrient Requirements of Pigs. Slough: Commonwealth Agricultural Bureaux.

Batterham, E. S., Andersen, L. M. \& Baigent, D. R. (1993). Utilization of ileal digestible amino acids by growing pigs: methionine. British Journal of Nutrition 70, 711-720.

Batterham, E. S., Andersen, L. M., Baigent, D. R., Beech, S. A. \& Elliott, R. (1990a). Utilization of ileal digestible amino acids by pigs: lysine. British Journal of Nutrition 64, 679-690.

Batterham, E. S., Andersen, L. M., Baigent, D. R. \& White, E. (1990 b). Utilization of ileal digestible amino acids by growing pigs: effect of dietary lysine concentration on efficiency of lysine retention. British Journal of Nutrition 64, 81-94.

Batterham, E. S. \& Murison, R. D. (1981). Utilization of free lysine by growing pigs. British Journal of Nutrition 46, 87-92.

Beech, S. A., Batterham, E. S. \& Elliott, R. (1991). Utilization of ileal digestible amino acids by pigs: threonine. British Journal of Nutrition 65, 381-390.

Black, J. L., Campbell, R. G., Williams, I. H., James, K. J. \& Davies, G. T. (1986). Simulation of energy and amino acid utilization in the pig. Research and Development in Agriculture 3, 121-145.

Burlacu, G., Baia, G., Ionila, D., Moisa, D., Tascenco, V., Visan, I. \& Stoica, I. (1973). Efficiency of the utilization of the energy of food in piglets after weaning. Journal of Agricultural Science, Cambridge 81, 295-302.

Campbell, R. G., Taverner, M. R. \& Rayner, C. J. (1988). The tissue and dietary protein and amino acid requirements of pigs from $8 \cdot 0$ to $20 \cdot 0 \mathrm{~kg}$ live weight. Animal Production 46, 283-290.

Degussa AG (1986). Determination of Raw Materials and Feedstuffs After Alkaline Hydrolysis and HPLC Detection. Analysis, A5. Hanau: Degussa AG.

Fuller, M. F. \& Wang, T. C. (1987). Amino acid requirements of the growing pig. In Manipulating Pig Production, pp. 97-111 [APSA Committee, editors]. Werribee: Australasian Pig Science Association.

Hugli, T. E. \& Moore, S. (1972). Determination of the tryptophan content of proteins by ion exchange chromatography of alkaline hydrolysates. Journal of Biological Chemistry 247, 2828-2834. 
Jordan, J. W. \& Brown, W. O. (1970). The retention of energy and protein in the baby pig fed on cows' milk. In Energy Metabolism of Farm Animals, pp. 161-164 [A. Schurch and C. Wenk, editors]. Zürich: Juris Druck and Verlag.

Lenis, N. P., van Diepen, J. Th. M. \& Goedhart, P. W. (1990). Amino acid requirements of pigs. 1. Requirements for methionine + cystine, threonine and tryptophan of fast-growing boars and gilts, fed ad libitum. Netherlands Journal of Agricultural Science 81, 577-595.

Standing Committee on Agriculture (1987). Feeding Standards for Australian Livestock. Pigs. East Melbourne: CSIRO.

Tanksley, T. D. \& Knabe, D. A. (1981). Use of cottonseed meal in swine rations. Feedstuffs 53, 24-27. 